DOI: $10.1515 /$ lpts-2016-0019

\title{
INVARIANT CONTROL OF THE TECHNOLOGICAL PLANTS TO COMPENSATE AN IMPACT OF MAIN DISTURBANCES PREEMPTIVELY
}

\author{
A. Sniders, A. Laizans, T. Komass \\ Latvia University of Agriculture, Faculty of Engineering, \\ Institute of Energetics \\ 5 J. Cakstes Blvd., Jelgava, LV-3001, LATVIA
}

The paper considers a survey of the research procedures and results due to invariant control method application perspective for operation quality advancement in several technological plants (wastewater biological treatment tanks and water steam production boilers), which operate under influence of organised and random disturbances. A specified subject of research is the simulation model of the multi-link invariant control system for steam pressure stabilisation in a steam boiler by preemptive compensation of steam load and feed water flow impact on output parameter (steam pressure), developed in MATLAB/SIMULINK. Simulation block-diagram of the steam boiler invariant control system, containing closed loop PID control circuit and open loop DPC circuit, has been composed on the basis of the designed mathematical model of the system components, disturbance compensation algorithms, and operational equation of the invariant control system. Comparative response of the steam boiler, operating under influence of fluctuating disturbances, with conventional PID control and using PID-DPC control with disturbance compensation controller DPC, has been investigated. Simulation results of invariant PID - DPC control system show that output parameter of the steam boiler pressure remains practically constant under fluctuating disturbances due to a high-speed response of DPC controller.

Keywords: controller, disturbance, invariant control, simulation model, steam boiler, technological plant, wastewater aeration.

\section{INTRODUCTION}

It is crucially important to have an appropriate option of technological processes and plant automatic control method and technical solution. It allows reducing operation costs due to minimisation of energy consumption, as well as increasing process stability and overall quality using an optimally selected control strategy. A topicality of urban environment is waste processing, including industrial and communal wastewater treatment, which accounts for a large part of municipality budget.

Wastewater cleaning is provided by biologically active sludge - a complex set of live cells, bacteria and microbes, which consume the waste. In order to facilitate 
metabolism, oxygen must be supplied and dissolved in the wastewater. Wastewater cleaning quality is controlled indirectly - by measuring oxygen concentration in water at the exit from cleaning facilities. Oxygen is supplied to the aeration tank using air blowers driven by variable-frequency electric motors. Thus, the inverter output frequency is the response to the dissolved oxygen concentration measured at the aeration tank exit [1]. As a wastewater aeration system is the main energy consumer up to $80 \%$ of wastewater processing plant, high control parameter level substantially increases the energy consumption and total expenses.

The main task of aerator control system is to keep dissolved oxygen concentration high enough - usually around $2 \mathrm{~g} \cdot \mathrm{m}^{-3}$ [1], [2]. Major perturbation that has direct impact on oxygen concentration over all aeration tank volume is variable wastewater afflux, and waste concentration in incoming wastewater. Research shows that wastewater concentration is affected by a precipitation level, and people's daily and weekly activity (variation is more than $200 \%$ ) [2], and wastewater afflux fluctuates by more than $40 \%$ on a daily basis, and by $50 \%$ on a monthly basis (mean monthly wastewater afflux for a town with 7000 inhabitants fluctuates from $800 \mathrm{~m}^{3}$ (December) to $1600 \mathrm{~m}^{3}$ (April) [3]).

If the dissolved oxygen concentration is too low, sludge metabolism stops, and wastewater is not cleaned. If low oxygen concentration occurs often and for long time, active sludge components die. It can take 3-6 months to restart a wastewater cleaning process. As this is a risk factor which has very strong negative impact, wastewater plant operators usually keep the dissolved oxygen concentration much higher than necessary - between 3 and $4 \mathrm{~g} \cdot \mathrm{m}^{-3}$. Such extremely high set points tremendously increase energy consumption and generate additional expenses.

PID controllers are widely used for wastewater aeration process automation, but the research shows low control quality and inability to respond adequately to both main perturbation variations because of several variables to be controlled [1], [2]. This is also the reason of keeping high dissolved oxygen concentration set points at the aeration tank exit. Simulation and experimental research have proven that an invariant control system can keep dissolved oxygen concentration near the set point with fluctuation less than $\pm 3 \%$ [4], and it reduces the energy consumption by more than $30 \%$ without any additional investments.

The additional challenges for wastewater aeration automatic control system designers are fluctuating inertia and sensitivity of the wastewater aeration tank [4]. Aeration tank inertia is between 40 and 90 minutes, depending on afflux and aeration tank size, sensitivity changes with waste concentration and waste composition. Adaptive PID-DPC control system, the parameters of which are correctly calculated according to the invariant control principle, cancels out the impact of perturbations fluctuating waste concentration and afflux [1], [2].

The other technological facilities with high impact of disturbances are the steam boilers as the energy conversion units, which transform the combustion energy of fuel into steam heat and mechanical power. High pressure steam boilers are applied in cogeneration plants. Low pressure steam is used for technological needs and autonomous heating of food production enterprises.

Main tasks of the steam boiler design, operation and automatic control are as 
follows: 1) to minimise heat losses from the furnace and boiler room using economizers, increasing heat resistance and fuel combustion efficiency, as well as optimising heat load control; 2) to reduce flue gas emissions using emission reduction facilities and applying burners optimal control; 3) to continuously measure, analyse and control inner technological parameters - steam pressure and temperature, drum water level and temperature, as well as main disturbances - feed water flow and steam flow that have direct impact on output parameters.

Conventional PID control is still the current tool for the steam boiler control [5]. The main control loop with only PID controller cannot eliminate an impact of disturbances efficiently enough because of delayed response to variable steam expenditure and feed water flow.

To increase operation stability and process control quality of the steam boilers and power plants, wide investigations of long-range control methods have recently been made: an active disturbance rejection control method, using multi-variable robust controllers with robustness against uncertainties and disturbances [5], [6]; an adaptive PID \& Fuzzy logic control for transient process optimisation [7]; an automatic reservation to compensate extreme overloads [8].

New approaches on the subject of development of the heat power unit-turbine control technology are complex control using linear hybrid automata [9] and invariance of multi-variable control [10]. General concept of steam boiler control improvement by active disturbance rejection is invariant control. Main advantages of this control method are verified in the simulation model of steam boiler output variable (steam pressure) control, invariant to steam flow [11].

The basic task of the given research is to develop and investigate the mathematical and simulation model of disturbance invariant PID-DPC control system for steam boiler, insensitive to variations of steam load and feed water flow.

\section{RESEARCH SUBJECT AND METHODS}

Research subject is the model of two-disturbance invariant control system of the steam boiler VAPOR TTK-70 with closed loop control link of steam pressure $\mathrm{p}(\mathrm{t})$, open loop control link of steam expenditure $q_{s}(t)$ and open loop control link of feed water supply $q_{w}(t)$ as the main disturbances of steam pressure.

The algorithms of the disturbance preemptive compensation (DPC) controller are compiled according to the invariant control principle in strong correlation with the algorithms of steam boiler and power supply unit, as well as steam flow and feed water flow impact on steam pressure. The transfer functions and operational equations of the steam boiler control system components are composed using mathematical analyses and operator mathematics.

For simplicity, heat transfer in the steam boiler is analysed as a process, where steam pressure changes uniformly with time, not position. Then the transient process can be described by the ordinary differential equations. Simplified linear model of steam boiler is used for no-load mode $\left(q_{s}(t)=0\right.$ and $\left.q_{w}(t)=0\right)$, as well as linear models of disturbances impact for a limited area of their changes.

Technical parameters of steam boiler VAPOR TTK-70 are as follows: heat 
power - $2 \mathrm{MW}$; rated steam capacity $-50 \mathrm{~kg} \cdot \mathrm{min}^{-1}$; max steam pressure $-10 \mathrm{bar}$; drum water capacity $-7700 \mathrm{~kg}$; steam temperature $-184{ }^{\circ} \mathrm{C}$; feed water temperature $-90{ }^{\circ} \mathrm{C}$; OILON burner GKP- 250M - (0.37-2.6) MW.

A functional block-diagram of invariant PID-DPC control system is shown in Fig. 1. Main control loop consists of the PID controller, the frequency converter and the actuator for power flow regulation, the controllable technological plant and the sensitive transducer for output parameter measurement and conversion.

To realise an invariance of the output parameter control, apart from variations of main disturbances D1 and D2, the disturbance controller DPC is introduced. According to measurement results of disturbance D1 and D2, the controller DPC produces output signal $X_{p c}$ for preemptive activation of frequency converter. Thereby, an actuator corrects the regulation impact - power flow in time and eliminates an output parameter change.

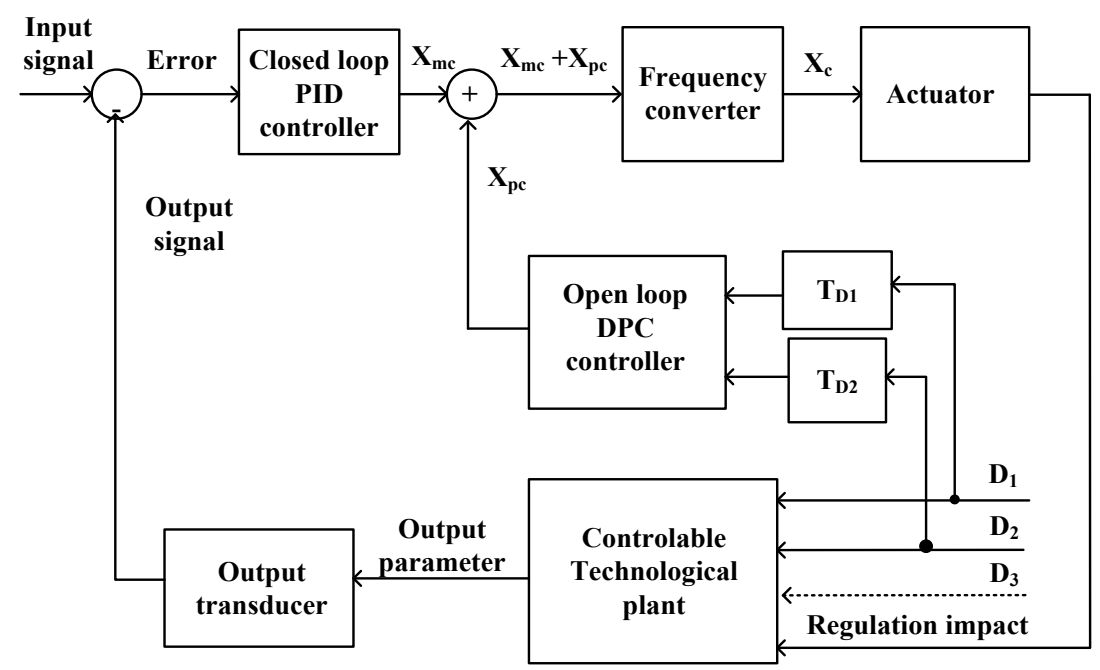

Fig. 1. Functional block-diagram of invariant PID - DPC control system: $\mathrm{X}_{\mathrm{mc}}$ - main control signal; $X_{p c}$ - preemptive control signal; $X_{c}$-frequency converter output signal; $\mathrm{D}_{1}, \mathrm{D}_{2}, \mathrm{D}_{3}-$ disturbances; $\mathrm{T}_{\mathrm{D} 1}, \mathrm{~T}_{\mathrm{D} 2}$ - transducers for main disturbances measurement.

\section{MATHEMATICAL AND SIMULATION MODELS}

The conventional algorithm of the PID controller, available in SIMULINK, is used. All constants of PID controller are tuned automatically during simulation process (Fig. 2). For no-load mode $\left(q_{s}=0, q_{w}=0\right)$ the steam boiler is considered to be two component volume (water + steam) unit with constant sensitivity and response parameters. In that case the transient process of pressure alteration can be described by second-order transfer function:

$$
G_{s b}(s)=\eta_{s b} \cdot p_{0}(s) \cdot Q_{f}(s)^{-1}=\eta_{s b} \cdot K_{s b} \cdot\left[T_{w} \cdot T_{s} \cdot s^{2}+\left(T_{w}+T_{s}\right) \cdot s+1\right]^{-1},
$$


where $Q_{f}(s), p_{0}(s)$ - Laplace transforms of furnace heat flow and steam pressure at no-load mode; $\eta_{s b}=0.93$ - efficiency factor of the boiler, using economizer; $K_{s b}=$ 11.5 bar $\cdot \mathrm{MW}^{-1}$ - transfer coefficient of steam boiler at ideal no-load mode; $T_{w}=5$ $\min , T_{s}=19 \mathrm{~min}-$ time constants of water and steam volumes.

Variable steam expenditure $q_{s}$ as a load has a directly negative effect on steam pressure in the boiler. Load growth causes pressure decrease for transient volume $\Delta p_{q s}$. This can be described by the following second order transfer function:

$$
G_{q_{s}}(s)=\Delta p_{q s}(s) \cdot q_{s}(s)^{-1}=K_{q s} \cdot\left[\tau_{q s} \cdot T_{q s} \cdot s^{2}+\left(\tau_{q s}+T_{q s}\right) \cdot s+1\right]^{-1},
$$

where $q_{s}(s), \Delta p_{q s}(s)$ - Laplace transforms of steam flow and steam pressure change; $K_{q \mathrm{~s}}=0.135 \mathrm{bar} \cdot \mathrm{min} \cdot \mathrm{kg}^{-1}$ - transfer coefficient of steam flow impact on steam pressure; $\tau_{q s}=5 \mathrm{~min}, T_{q s}=7 \mathrm{~min}$ - dead time and time constant of steam flow.

Feed water flow $q_{w}$ is regulated by frequency controlled centrifugal pumps in correlation with the steam expenditure and causes additional change of common steam pressure in the boiler for transient volume $\Delta p_{q w}$ that can be described by the following second order transfer function:

$$
G_{q_{w}}=\Delta p_{q w}(s) \cdot q_{w}(s)^{-1}=K_{q s} \cdot\left[\tau_{q w} \cdot T_{q w} \cdot s^{2}+\left(\tau_{q w}+T_{q w}\right) \cdot s+1\right]^{-1},
$$

where $q_{w}(s), \Delta p_{q w}(s)$ - Laplace transforms of feed water flow and steam pressure change; $K_{q \mathrm{w}}=0.038 \mathrm{bar} \cdot \mathrm{min} \cdot \mathrm{kg}^{-1}-$ transfer coefficient of feed water flow impact on steam pressure; $\tau_{q w}=2 \mathrm{~min}, T_{q w}=7 \mathrm{~min}$ - dead time and time constant of feed water flow impact.

The heat power actuator consists of frequency converter; servomechanism with servomotor and feedback for stability improvement, gas and air valves; and furnace. According to the block-diagram (Fig. 2), the transfer function of the actuator input-output link for transient process simulation is compiled:

$$
G_{a}(s)=Q_{f}(s) \cdot i_{a}(s)^{-1}=\left[K_{f b}^{-1} \cdot\left(K_{g v}+K_{a v}\right) \cdot K_{f}\right] \cdot\left[\left(K_{c} \cdot K_{s m} \cdot K_{f b}\right)^{-1} \cdot s+1\right]^{-1}=K_{a} \cdot\left(T_{a} \cdot s+1\right)^{-1},
$$

where $i_{a}(s), Q_{f}(s)$ - Laplace transforms of actuator input signal and furnace heat flow; $K_{c}=2.5 \mathrm{~Hz} \cdot \mathrm{mA}^{-1}-$ transfer coefficient of frequency converter; $K_{f b}=4.5 \mathrm{~mA} \cdot \mathrm{rad}^{-1}$ transfer coefficient of servomechanism feedback; $K_{s m}=0.063$ radians $\cdot \min ^{-1} \cdot \mathrm{Hz}^{-1}$ speed coefficient of servomotor; $K_{g v}=2.5 \mathrm{~m}^{3} \cdot \mathrm{min}^{-1} \cdot \mathrm{rad}^{-1}-$ transfer coefficient of gas valve; $K_{a v}=24 \mathrm{~m}^{3} \cdot \mathrm{min}^{-1} \cdot \mathrm{rad}^{-1}-$ transfer coefficient of air valve; $K_{f}=0.043 \mathrm{MW} \cdot \mathrm{m}^{-}$ ${ }^{3} \cdot \mathrm{min}$ - transfer coefficient of furnace; $K_{a}=0.24 \mathrm{MW} \cdot \mathrm{mA}^{-1}-$ transfer coefficient of actuator; $T_{a}=1.4 \mathrm{~min}$ - time constant of actuator response.

Main task of the steam boiler control system is to ensure perfect compensation of the physical impact of variable steam expenditure $q_{s}(t)$ and feed water flow $q_{w}(t)$ on steam pressure $p(t)$ by using the disturbance preemptive compensation controller, which operates according to the invariant control principle.

The mathematical model of steam boiler invariant control system, containing a steam pressure closed loop PID control circuit and steam flow, and feed water flow open loop DPC control circuits, is the following operational equation: 


$$
\begin{aligned}
& p(s)=\left[i_{0}(s) \cdot G_{P I D}(s) \cdot G_{a}(s) \cdot G_{s b}(s)+\left(K_{s f} \cdot G_{s}(s) \cdot G_{a}(s) \cdot G_{s b}(s)-G_{q s}(s)\right) \cdot q_{s}(s)+\right. \\
& \left.+\left(K_{w f} \cdot G_{w}(s) \cdot G_{a}(s) \cdot G_{s b}(s)-G_{q w}(s)\right) \cdot q_{w}(s)\right] \cdot\left(K_{p} \cdot G_{P I D}(s) \cdot G_{a}(s) \cdot G_{s b}(s)+1\right)^{-1},
\end{aligned}
$$

where $q_{s}(s), q_{w}(s)$ - Laplace transforms of main disturbances (steam flow and feed water flow); $K_{s f}, K_{w f}=0.2 \mathrm{~mA} \cdot \mathrm{kg}^{-1} \cdot \mathrm{min}$ - transfer coefficients of steam and feed water flowmeters; $G_{s}(\mathrm{~s}), G_{w}(\mathrm{~s})$ - unknown transfer functions of steam and feed water disturbances controller.

In conformity with the invariant control principle, the following conditions of the process invariance can been formulated: if $K_{s f} \cdot G_{s}(s) \cdot G_{a}(s) \cdot G_{s b}(s)-G_{q s}(s)=0$ and $K_{w f} \cdot G_{w}(s) \cdot G_{a}(s) \cdot G_{s b}(s)-G_{q w}(s)=0$, then the disturbances $q_{s}(t)$ and $q_{w}(t)$ do not affect the transient process in the steam boiler.

Considering that $\mathrm{T}_{\mathrm{a}}<0.1 \mathrm{~T}_{\mathrm{sb}}$, the algorithms of the disturbance (steam expenditure and feed water flow) preemptive compensation controller DPC should be composed according to such transfer functions:

$$
\begin{aligned}
& G_{s}(s)=G_{q s}(s) \cdot\left(K_{s f} \cdot G_{a}(s) \cdot G_{s b}(s)\right)^{-1} \approx 0.245 \cdot\left(130 \cdot s^{2}+25 \cdot s+1\right) \cdot\left(35 \cdot s^{2}+12 \cdot s+1\right)^{-1} \\
& G_{w}(s)=G_{q w}(s) \cdot\left(K_{w f} \cdot G_{a}(s) \cdot G_{s b}(s)\right)^{-1} \approx 0.071 \cdot\left(130 \cdot s^{2}+25 \cdot s+1\right) \cdot\left(35 \cdot s^{2}+12 \cdot s+1\right)^{-1}
\end{aligned}
$$

The transfer functions (6), (7) describe conditions of disturbance impact on steam boiler preemptive compensation. The block-diagram is compiled in SIMULINK for the steam boiler control system simulation and transient process comparative analysis of conventional PID control model and invariant PID-DPC control model with disturbance controller (Fig. 2).

The main closed loop control circuit consists of the following models: a "PID Controller" model with limited output $( \pm 20 \mathrm{~mA})$, auto-tuning of control circuit parameters and activated Wind-up function for transient process optimisation; an actuator model for heat power supply regulation with operation algorithm (4) ("Converter", "Servomotor" with "Feedback" to improve the control stability; "Air Valve" and "Gas Valve" for gas mixture flow regulation on "Furnace"); a "Steam boiler" model composed as a subsystem with operation algorithms of heat flow regulation effect (1), steam flow disturbance effect (2) and feed water flow disturbance effect (3) on steam pressure; a "Pressure transducer" for steam pressure continuous measurement.

For simulation of heat flow effect on steam pressure an open access - free access SIMULINK model of the steam boiler transfer function (1) is compiled, using closed loop circuits with integrators and math operation blocks that make possible to enter the model parameters - process sensitivity and dynamics indices (transfer coefficients and time constants) during all the simulation time.

Main advantage of open access structure is a possibility to make an adaptive self-tuning model for adequate simulation of non-stationary technological process if sensitivity and dynamics indices of the technological unit are not constant, but vary with disturbances substantially [12]. 


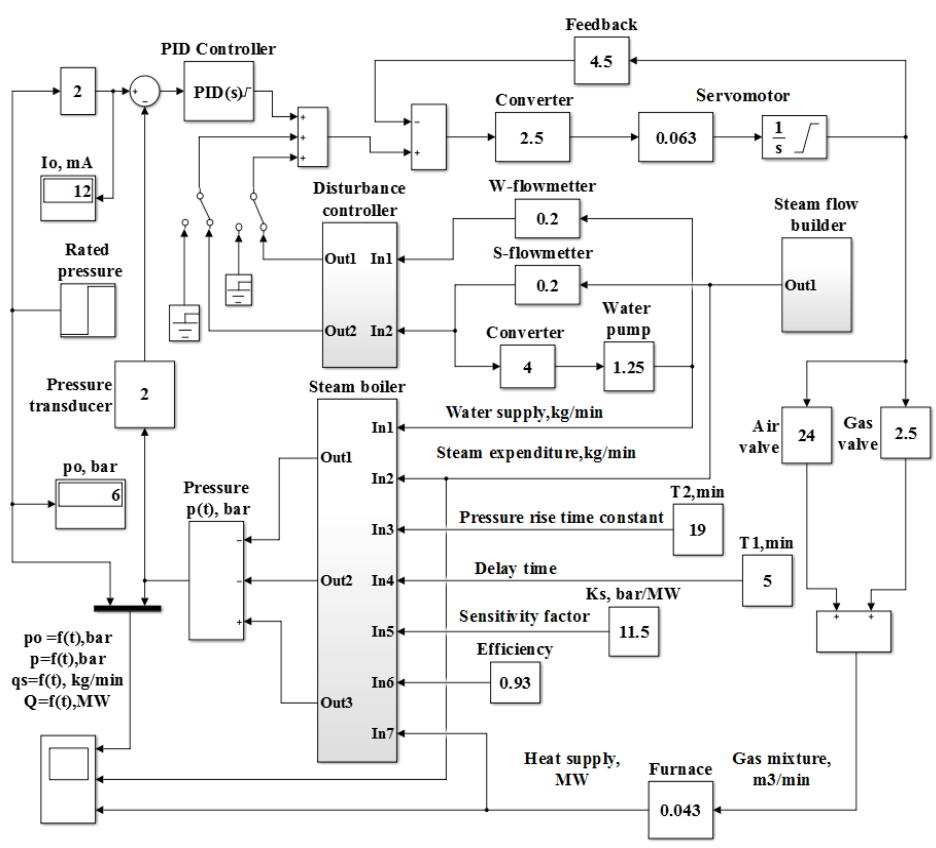

Fig. 2. Simulation block-diagram of steam boiler PID - DPC control system.

To perform constant, linear, pulse case and randomly changing components of steam flow $\mathrm{q}_{\mathrm{s}}(\mathrm{t})(\mathrm{kg} / \mathrm{min})$, as a load and main disturbance of the steam boiler, a "Steam flow builder" model is applied.

The simulation model of the "Disturbance Controller" DPC is performed according to algorithms (6), (7) as coupled second order differential filters. Steam flow and feed water flow are measured by "S - flowmeter" and "W - flowmeter". To minimise disturbance on steam pressure, the feed water flow to steam boiler has been delivered continuously in close correlation with steam expenditure flow, applying "Water pump" with frequency "Converter" controlled asynchronous electrical drive, whose productivity rate is $1.25 \mathrm{~kg} \cdot \mathrm{min}^{-1} \cdot \mathrm{Hz}^{-1}$.

\section{SIMULATION PROCEDURES AND RESULTS}

Simulation comparative results of the steam boiler conventional PID control system and invariant PID - DPC control system are presented in Fig. 3. To search for a wide spectrum of steam flow $q_{s}(t)$, as a load on steam boiler, influence on the steam pressure $\mathrm{p}(\mathrm{t})$, the simulation time should be long enough because of high steam pressure transient process time $\left(t_{t r} \geq 4 \mathrm{~T}_{\mathrm{sb}} \approx 4 \cdot 19=76 \mathrm{~min}\right)$.

Simulation is started at no-load mode with zero disturbances (steam load $\mathrm{q}_{\mathrm{s}}(\mathrm{t})=0$ and feed water flow $\left.q_{w}(t)=0\right)$. Afterwards, the transient steam pressure reaches set point -6 bar and becomes stable, the linear growing load (rise ramp 3.3 $\mathrm{kg} \cdot \mathrm{min}^{-2}$ ) from zero to rated value $-50 \mathrm{~kg} \cdot \mathrm{min}^{-1}$ is activated. To search for steam boiler reaction on steam flow large and fast perturbations, a linear growing overload ( $+40 \%$ of rated value) and linear changing under load (-40\% of rated value) are added. After 100 minutes from the start, a random component with amplitude $\pm 10 \%$ of rated value and frequency $0.5 \mathrm{~min}^{-1}$ is added $\left(q_{s}(t)\right.$ in Fig. 3$)$. 
Simulated response of steam pressure $p(\mathrm{t})$ change in the steam boiler feedback control system with optimally tuned PID controller shows that the overshoot of the steam pressure run up process is below $10 \%$ and response time does not exceed 20 minutes. Under fast growing load from zero to rated value, the steam pressure response curve has the maximum deviation up to $50 \%$. Under linear and step case load variations ( $\pm 40 \%$ of rated value) $p(t)$ maximum deviations reach up to $\pm 25 \%$ of rated value $\left(p_{1}(t)\right.$ in Fig. 3). It testifies that the feedback control system with PID controller is sufficiently stable and fast in operation under no-load or constant load conditions, but operation quality is insufficient under substantially variable load. Due to response inertia of PID controller, the heat power regulation is delayed and therefore is not efficient enough $\left(Q_{1}(t)\right.$ in Fig. 3) and disturbance rejection is too late that cause great deviations of control parameter $\mathrm{p}_{1}(\mathrm{t})$.

Activation of steam pressure $p(t)$ main disturbance (steam expenditure as a load of the steam boiler) compensation link of the Disturbance controller ("Out 2 " in Fig. 2), operation algorithm of which (6) is compiled in accordance with the invariance conditions, shows that maximum deviation of rated steam pressure $(6$ bar) decreases from $50 \%$ to $14 \%$ in comparison with only PID control $\left(p_{2}(t)\right.$ in Fig. $3)$. Disturbance impact on the steam pressure is substantially eliminated by efficient regulation of the heat power flow $\left(Q_{2}(t)\right.$ in Fig. 3).

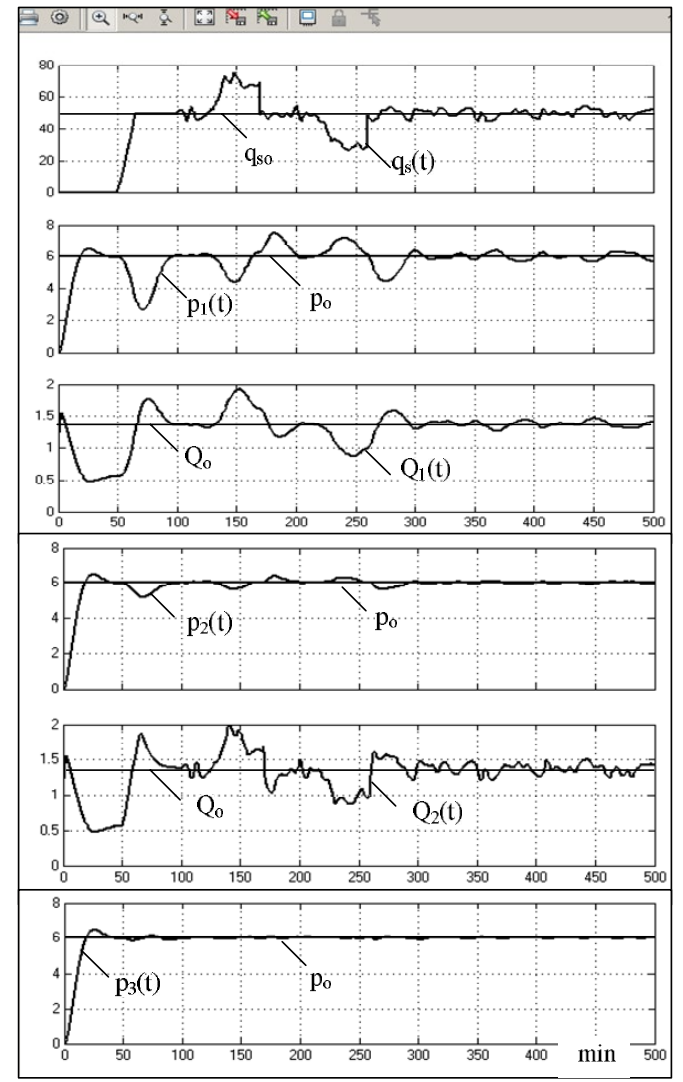

Fig. 3. Transient characteristics of the steam pressure $\mathrm{p}(\mathrm{t})(\mathrm{bar})$ and heat flow $Q(t)(\mathrm{MW})$ control model under randomly varying steam flow $q_{s}(t)(\mathrm{kg} / \mathrm{min})$ and water flow $q_{w}(t)(\mathrm{kg} / \mathrm{min}): p_{1}(t)$,

$Q_{1}(t)$ - PID control; $p_{2}(t), Q_{2}(t)-(\mathrm{PID}+\mathrm{DPC})$ control invariant to $q_{s}(t) ; p_{3}(t)-(\mathrm{PID}+\mathrm{DPC})$ control invariant to $\left(q_{s}(t)+q_{w}(t)\right) ; p_{0}, Q_{0}, q_{s 0}$ - rated values of main technological variables. 
Simulated response of steam pressure invariant PID-DPC control system with two disturbance $\left(q_{s}(t)+q_{w}(t)\right)$ preemptive compensation controller, the parameters of which are calculated and tuned according to the invariant control algorithms $(6,7)$, shows that the process parameter $p(t)$ remains practically constant under any type of steam expenditure - constant, steady changing, pulse or randomly fluctuating ( $p_{3}$ (t) in Fig. 3). If the steam flow deviates by $\pm 25 \%$ from the rated value, deviations of the steam pressure do not increase by $\pm 3 \%$ of set point value. High quality of steam pressure stabilisation is reached due to fast and synchronous compensation of disturbance impact on control transient process.

\section{CONCLUSIONS}

1. The research proves that stability and high quality operations of the technological processes with randomly variable perturbations (wastewater biological cleaning, steam production, etc.) can be realised using invariant control system with major disturbance impact preemptive compensation on control object output parameters.

2. A steam boiler invariant PID-DPC control system with disturbances preemptive compensation controller, the algorithm and parameters of which are correctly compiled according to the invariant control principle, cancels out the impact of main external disturbances - the fluctuating steam expenditure $q_{s}(t)$ and the feed water flow changes $q_{w}(t)$ on the steam boiler output variable - steam pressure $p(t)$.

3. Simulations show that for steam boiler feedback control system with only PID controller and optimally tuned parameters the maximum deviation of the control variable - steam pressure $p(t)$ is up to $50 \%$ under linear growing rate of steam expenditure from no-load to rated value, showing overall unacceptable control quality and inability to compensate fast variable disturbances.

4. Simulation results make possible to forecast that introducing in practice the invariant PID-DPC control system with disturbances $q_{s}(t)$ and $q_{w}(t)$ preemptive compensation controller, the fluctuations of boiler steam pressure $p(t)$ do not exceed \pm 3 $\%$ of rated value because of high sensitivity of disturbance controller and high-speed response of systems actuator to disturbances.

5. The developed methodology of invariant control system modelling and design for wastewater aeration and water steam production plants can be successfully applied to other technological processes and plants to be characterised by high influence of organised and randomly varying disturbances.

\section{REFERENCES}

1. Sniders, A., and Laizans, A. (2006). Invariant control of wastewater aeration. Advances in Computer, Information, and Systems Sciences, and Engineering, Univ. of Bridgeport, Inst. of Electrical and Electronics Eng. (IEEE), Bridgeport, USA: Springer, 99-103.

2. Laizans, A., and Sniders, A. (2008). Simulation of cost-efficient wastewater aeration control using invariant control Principle. Sc. J. Agriculture and Engineering Complying with the European Requirements, Bucharest, Romania, INMATEH Magazine, 24(I), 183-187. 
3. Sniders, A., Laizans, A. (2007). Computer aided modelling of wastewater aeration. In Conf. Proc. Rural Development 2007, 8-10 November 2007. (pp. 227-231) 3 (2), Kaunas, Lithuania: Lith. Univ. of Agric.

4. Sniders, A., and Laizans, A. (2011). Adaptive model of wastewater aeration tank. Sc. J. of Riga Tech. Univ. Environmental and Climate Technologies. (13) 6, 112-117.

5. Qinling, Z., Zhiqiang, G., and Wen, T. (2011). Disturbance rejection in thermal power plants. In 30th Chinese Control Conference, 22-24 July, (pp. 6350-6355), Yantai, China.

6. Ivezic, D., and Petrovic, T. (2010). Robust IMC controllers with optimal set-points tracking and disturbance rejection for industrial boiler. J. Mechanical Engineering, vol. 56, (565-574).

7. Sniders, A., and Rungulis, D. (2001). Adaptive control of the steam boiler for process needs in food production plant. Sc. J. Industrial Heat Engineering, National Academy of Sciences, Ukraine. 23 (3), 89-95. (In Russian).

8. Sniders, A. (2003). Transient process stabilization in a steam boiler. Sc. J. of Riga Tech. Univ. Power and Electrical Engineering, 4 (9), 166-171, ISSN 1407-7345. (In Latvian).

9. Henzinger, A., and Wong-Toi, H. (1996). Using HYTECH to Synthesize Control Parameters for Steam Boiler. Lecture Notes in Computer Science, University of California, Berkeley: Springer-Verlag.

10. Navritil, A., Pekar, L., and Masaryka, T.G. (2011). Possible solution of decoupling and invariance of multi-variable control loop by using correction members. WSEAS Transactions on Circuits and Systems, 6 (10), 209-219.

11. Sniders, A., and Komass, T. (2012). Invariant method of load independent pressure control in steam boiler. Sc. J. of Riga Tech. U. Electrical, Control and Communication Engineering. 1 (1), 5-10.

12. Sniders, A. (2010). Adaptive self-tuning model for non-stationary process simulation. In Conf. Proc. Engineering for Rural Development 2010, 27-28 May 2010 (pp.192-199) Vol. 9, Jelgava, Latvia: LUA, Fac. of Engineering.

\title{
TEHNOLOGISKO IEKĀRTU INVARIANTA VADĪBA GALVENO PERTURBÄCIJU IESPAIDA APSTEIDZOŠAI KOMPENSĀCIJAI
}

\author{
A. Šnīders, A. Laizāns, T. Komass
}

Kopsavilkums

Rakstā piedāvāts pārskats par pētījumu rezultātiem, kas apliecina invariantās vadības metodes priekšrocības tehnolog̣isko iekārtu, uz kurām iedarbojas būtiskas organizētas un stohastiskas perturbācijas kā, piemēram, notekūdenuu biolog̣iskās attīrīšanas aerotenki un tvaika katli pārtikas produktu apstrādei ar tvaiku, darb̄̄bas procesu vadības kvalitātes un energoefektivitātes uzlabošanai. Kā specifisks izpētes objekts apskatīts tvaika katla daudz-kontūru invariantās vadības sistēmas simulācijas modelis MATLAB/SIMULINK vidē. Sistēma sastāv no slēgtas cilpas vadības kontūra ar tradicionālo PID kontrolleri un tvaika spiediena mērīšanas pārveidotāju atgriezeniskajā saitē, un perturbāciju (tvaika patēriņa slodzes un pievadītā ūdens plūsmas) iespaida apsteidzošas kompensācijas vaḷējas cilpas kontūriem ar divkanālu 
kontrolleri DPC, kurš apsteidzoši aktivizē tvaika katla enerǵētisko iekārtu, tiklīdz mainās kāda no perturbācijām, un tādā veidā savlaicīgi novērš spiediena izmaiṇu tvaika katlā. PID kontrolleris reaǵē uz perturbācijām novēloti, pēc tam kad vadības objektā jau notikušas būtiskas izmaiņas, un bez DPC kontrollera atbalsta nespēj nodrošināt atbilstošu tvaika spiediena stabilitāti pie straujas tvaika patēriņa izmaiņas. DPC kontrollera darbības algoritmi sastādīti atbilstoši invariances prasībām ciešā korelācijā ar vadības objekta un enerğētiskās izpildiekārtas darbības algoritmiem, to jutības un reakcijas laika parametriem. Simulācijas rezultāti apliecina, ka pateicoties DPC kontrollera adekvātai reakcijai gan uz organizētām, gan stohastiskām perturbācijām, to iespaids uz vadības objekta stabilizējamo izejas parametru tiek savlaicīgi kompensēts ar enerǵētiskās iekārtas apsteidzošu, paātrinātu ierosināšanu, apejot galveno PID vadības kontūru.

11.05.2016. 